\title{
La universalidad de la reflexión ética mesoamericana
}

\author{
Jordi Corominas
}

Una moral que no resista la prueba de la universalidad está minada radicalmente por su propia base

\section{Resumen}

El presente artículo plantea la interrogante, a partir de un contexto filosófico, de si se debe acceder a algún tipo de universalidad relevante para la reflexión ética, o si es preciso abandonar esta idea como un residuo laico de religiones universalistas. En este sentido, existen diversos planteamientos universalistas que no brindan un criterio absoluto, sino que proporcionan una serie de orientaciones. Por tanto, es preciso analizar la universalidad a partir de sus distintas dimensiones. La dimensión fáctica muestra que la actuación se rige por la intencionalidad; la dimensión racional de la moral permite crear nuevos esquemas intencionales, la modificación de actuaciones y la creación de nuevas; la dimensión protomoral que comprende los actos de sensación, afección y volición que conllevan un criterio para decidir sobre la bondad y la maldad. Por consiguiente, la universalidad ética encuentra su respuesta en una ética filosófica, entendida como filosofía primera. La ética primera puede acceder a una verdadera universalidad y es aprobatoria si reconoce el pluralismo en todos los ámbitos (económico, cultural, político, etc.). 
Diversos filósofos latinoamericanos han puesto una y otra vez en evidencia que el universalismo ético es una máscara del etnocentrismo y un instrumento ideológico excelente para legitimar los procesos de colonización y las relaciones de dominio. En cambio, diversas filosofías de la liberación y descolonización ven en el relativismo cultural un arma liberadora para transformar en motivo de orgullo las maneras de ser que pretendían avergonzarles, y para defender otras formas de organización política y económical. Desde este relativismo se suele abogar a veces por el diálogo y el respecto intercultural. Se trataría de favorecer sobre todo el respeto a la diferencia y recuperación de la identidad perdida o robada como única posibilidad para hacer frente a la imposición cultural.

El punto de partida aquí sería la sabiduría popular, "la hermenéutica de los signos, la historia y la cultura latinoamericana" 2 . Esta vertiente culturalista de las filosofías latinoamericanas, que hunde sus raíces en Heidegger y la tradición hermenéutica, parecería encontrar un profundo eco en un cierto pensamiento postmoderno. Sin embargo, hay que andarse con tiento porque, aunque las palabras sean las mismas, el relativismo cultural postmoderno es muy diferente del relativismo preconizado por el común de las filosofías de la identidad y las filosofías de la descolonización. A los ojos de la postmodernidad las filosofías de la identidad desarrolladas en el sur son una especie de viudas desconsoladas de la era autoritaria. Lo que nos propone ésta, no es la fidelidad a las raíces, sino una especie de alegre mescolanza y multiculturalidad en la que toda práctica cultural, ya se trate de un reality show, un streaptease, un concierto o una labor humanitaria, tengan el mismo rango. El relativismo ético de uno y otro signo, no es desde luego infructífero. Por ejemplo, algunas teóricas feministas heideggerianas nos han hecho ser mucho más sensibles a las reivindicaciones de otros feminismos. Algunas feministas musulmanas, ante el escándalo de los rituales de ablación clítoridiana en occidente, reivindican que éstos se hagan con garantías, en hospitales públicos, y nos ilustran sobre la existencia de no menos de seis tipos de rituales, algunos semejantes a la circuncisión masculina, donde no se pierde la capacidad para experimentar placer. Claro está, aun las feministas que abogan por esta comprensión, en el fondo, la consideran como la mejor estrategia para la erradicación de estas prácticas ${ }^{3}$. No obstante, el problema ético de fondo que aquí nos planteamos es dónde poner el límite a la tolerancia, pues por más variedades de rituales clitoridianos iniciáticos que existan, algunos constituyen, sin duda, una auténtica mutilación genital. ¿Estas mutilaciones, como toda otra práctica, quedan legitimadas por una determinada tradición cultural y porque en ellas las mujeres la acepten sin aspavientos?

Muchos de los que defienden el relativismo ético no se lo suelen tomar muy en serio desde el momento que apelan al diálogo intercultural o a un aprendizaje entre las diferentes culturas. El diálogo intercultural sería un valor más en una determinada cultura que no se ve porque tiene que ser considerada mejor que la cultura que lo niegue. Si no hay ningún criterio supracultural, ¿cómo discriminamos entre unos valores y otros? ¿Qué seleccionamos y que descartamos de cada cultura? Los campos de concentración, los homos crematorios, los sacrificios humanos y todo tipo de horrores pueden ser perfectamente legitimados desde una tradición o cultura nacional. Pero lo más grave, alí donde el relativismo ético se cae por su propia base, es que, de hecho, lo que desde el punto de vista histórico podría ser cierto, en el presente no lo es. Hoy conformamos una única sociedad mundial, con muchísimas diferencias culturales, costumbres, hábitos, dioses, valores y concepciones dispares, pero con un único sistema mundial y una única estructuración de las formas de vida. Un sistema que necesita para constituirse como tal esta disparidad4.

1. Véase J. C. Scannone, Nuevo punto de partida de la filosofía latinoamericana, Buenos Aires, 1990; R. Kush, El pensamiento indígena latinoamericano, Puebla, 1970; F. Fanon, Les damnés de la terre, Maspero, 1961; S. Amín, El eurocentrismo, crítica de una ideología, 1989.

2. J. C. Scannone, Nuevo punto de partida de la filosofía latinoamericana, Buenos Aires, 1990.

3. Véase el debate al respecto entre las feministas de la diferencia y las feministas de la igualdad, cuyo trasfondo filosofico se identifica con nuestro tema. La librería de mujeres de Milán, en el artículo "El final del patriarcado", Viejo Topo, mayo (1996), sostiene una posición hermenéutica y postmoderna; Celia Amorós en el artículo "La política, las mujeres y lo iniciático", Viejo Topo, octubre (1996), replica defendiendo una posición universalista de tradición ilustrada.

4. A. González, Un solo mundo. Tesis doctoral, Comillas, Madrid, 1995. 
Podrá discutirse todo lo que se quiera la perversidad del universalismo ético, la función política e imperialista de la universalidad ilustrada, pero hoy la universalidad es un hecho, un dato que nos arrojan los análisis sociológicos más elementales. El relativismo ético permanece ciego ante esta universalidad fáctica que determina incluso muchas de las diferencias culturales. Su idea de incomunicabilidad e inconmensurabilidad cultural es sencillamente falsa, porque se da una comunicación física mundial previa a todo valor y sentido cultural. Y lo que es peor, hoy una de las armas para mantener esta universalidad fáctica es el relativismo ético y cultural, puesto que el sistema mundial vigente dejaría de ser viable en el momento en que la mayoría de los seres humanos compartiera el modus vivendi de los países ricos. Por tanto, nada tiene de sorprendente que hoy el relativismo ético ya no sea una concepción propia de los movimientos emancipadores ni de los pueblos colonizados, y que lo subscriban también aquellos que denuncian la invasión progresiva de Europa y Estados Unidos por los "colonos" de los países pobres que, con su afluencia masiva, pondrían en peligro la identidad cultural occidental.

El contrasentido se halla más bien en que se entienda toda formulación universalista, en los países pobres, como un neoimperialismo o una continuidad de la voluntad colonial. Sencillamente, ya no queda nada por colonizar, y la amenaza que pesa sobre un buen número de pueblos de Asia, Africa y América Latina no es el neoimperialismo, sino el abandono puro y simple, el convertirse en pueblos sobrantes y desechados, dependientes de la arbitraria caridad internacional5. Nos encontramos con un gran auge del relativismo ético, justamente cuando todos los grupos sociales del planeta, lo sepan y les guste o no, están más unificados que nunca.
En este contexto, Dussel, Ellacurfa y otros representantes de la filosoffa de la liberación latinoamericana, sin dejar de criticar un determinado tipo de universalismo etnocentrista, apelan a un modelo de universalismo ético que no excluya a nadie, ni a las clases marginadas, ni a las mujeres, ni a ninguna minoría. Se suele coincidir en que el requisito de universalidad y de ausencia de excepciones que trascienda la opinión o el acuerdo de la mayoría es indispensable para hablar de moral. La dificultad estriba en que en un sinnúmero de planteamientos se muestra la necesidad de algún tipo de universalidad ética sin una justificación clara y distinta de la misma o, lo que es más endeble, se incurre en una especie de falacia. Se pretende derivar de la necesidad de algún tipo de universalidad para que pueda haber exigencia ética la demostración de su existencia. "Si Dios no existe todo está permitido" afirmaba Dostoievski, "sin universalidad ética estamos fritos", parecen concluir muchos de los intentos de fundamentación ética. Numerosos filosofos abandonarán la investigación ética, bien por considerarla un ámbito oscuro, bien por juzgar que es el lugar donde la filosofía se traiciona a sí misma. La interrogante que nos planteamos en este trabajo es si desde el mero análisis filosófico accedemos a algún tipo de universalidad relevante para la reflexión ética o si, por el contrario, debemos abandonar esta idea como un residuo laico de religiones universalistas.

\section{La insatisfacción con los planteamientos universalistas vigentes}

Uno de los libros más vendidos y con más ediciones en el mundo de habla hispánica es sin duda la Etica de Sánchez Vázquez. Este libro, editado en México, en 1969, ha pasado por las

5. Tanto Pascual Brukner en La tentación de la inocencia, Barcelona, 1996, como Alain Finkielkraut en La derrota del pensamiento, Barcelona, 1990, desarrollan una crítica interesante al relativismo cultural y enfatizan la necesidad de un criterio universal allende las culturas, pero no llegan a elaborarlo. 
manos de muchas generaciones universitarias y trató de fundamentar filosóficamente una moral válida para todos los seres humanos. Son incontables los méritos de Sánchez Vázquez, sin embargo, hay algo que, quizás por los años que nos separan de la publicación de esta obra, nos produce insatisfacción, y es que, después de considerar que ni la sociología, ni la lógica, ni la ciencia pueden brindarnos un criterio radical y último de valoración ética, apela a la dialéctica y a un progreso histórico donde el último estado del proceso sería el superiorb. Se aferra, en definitiva, a una metafísica que no está radicalmente justificada. La universalidad ética preconizada por Sánchez Vázquez depende de la universalidad de su teoría de la historia, y ésta es más que problemática por la índole misma de cualquier teoría científica o metafísica que es provisional y abierta permanentemente a su refutación. Es decir, no se ve de ningún modo cómo una teoría de la historia puede proveer una fundamentación ética.

Carlos Beorlegui, ya en nuestra década?, considera que los elementos centrales de la ética del discurso de Apel resultan una base suficiente para asentar un modelo de ser humano solidario y liberador y que, con algunos complementos, podría constituir esta anhelada fundamentación universal y radical de la ética, accesible para cualquiera y no dependiente de ninguna teoría epistemológica o metafísica. Pero Antonio González ${ }^{8}$ ha mostrado con agudeza que las éticas del discurso son proclives a la legitimación de una forma de vida concreta, no por un mero desliz accidental de alguno de sus promotores, o por simples condicio namientos sociológicos de la teoría, corregibles desde la misma apelación a la comunidad ideal del diálogo, sino por el mismo punto de partida de la ética del discurso. Se sienta como un hecho el valor primero del discurso (diálogo, consenso, etc.) que coadyuvan las instituciones y las formas de vida occidental. De ese modo, lo último que se cuestiona es este estilo de vida y las instituciones que lo hacen posible. Al presuponer el valor supremo del diálogo, se acreditan las instituciones y las formas de vida que la posibilitan, pero que no son, de hecho, universalizables. Como denotan muchos de los textos de Apel, siempre se da por supuesto que los países occidentales están más cerca de la comunidad ideal de comunicación que los países pobres, su manera de vivir parece gozar de una mayor legitimidad ética que la de otras culturas.

Ignacio Ellacuría nos lleva justo a la consideración contraria. Algunas formas de vida de los países pobres, de las culturas indígenas y marginadas, tienen mayor autoridad ética, porque pueden ser universalizadas: "La oferta de humanización y libertad que hacen los países ricos a los países pobres no es universalizable $y$, por consiguiente, no es humana, ni siquiera para quienes la ofrecen. El agudo planteamiento de Kant podría aplicarse a este problema [...] Si el comportamiento y aún el ideal de unos pocos no puede convertirse en comportamiento y en realidad de la mayor parte de la humanidad, no puede decirse que este comportamiento y este ideal sean morales $y$, ni siquiera humanos; cuanto más, si el disfrute de unos pocos se hace a costa de la privación de los demás. En nuestro mundo, el ideal práctico de la civilización occidental no es universalizable, ni siquiera materialmente, por cuanto no hay recursos materiales en la tierra para que todos los países alcancen el mismo nivel de producción y consumo,

6. Sánchez Vázquez, Etica, 40 edición, México, 1969.

7. C. Beorlegui. "El problema antropológico desde la óptica de la liberación", Hacia una filosofía liberadora, San Salvador, 1995.

8. Todo este artículo está basado en la lectura del borrador del libro de Antonio González, Filosofía primera, que amablemente nos cedió.

9. La anécdota que refiere Antonio es que mientras Apel y Ellacuría reconocen el mismo hecho, la imposibilidad de universalizar la forma de vida occidental, las consecuencias que sacan son distintas. Para el primero se trata de que los países pobres aprendan a distinguir entre una auténtica calidad de vida y el nivel de vida de los paŕses ricos, para el segundo de que si los parses ricos no pueden universalizar sus formas de vida, entonces, estas son éticamente reprobables. Antonio González, Apuntes. Es importante resaltar que Apel sigue manteniendo ante las críticas latinoamericanas la teoría desarrollista. Lo único que concede es que hay problemas en las etapas del desarrollo, debido al bloqueo de los parses más ricos a la evolución progresiva de los más pobres y que sería muy bueno "que los habitantes de los llamados parses subdesarrollados no imitaran la forma específica de progreso en el desarrollo que han seguido los pueblos ricos del norte durante el último siglo". Véase K. Apel, "La pragmática trascendental" en E. Dussel, Debate en tomo a la ética del discurso de Apel, pp. 50 y ss. 
usufructuado hoy por los países llamados ricos, cuya población no alcanza el 25 por ciento de la humanidad"10. Ellacuría destaca como criterio y principio ético fundamental el principio de universalización que, como él mismo nos aclara inmediatamente, no es un principio de uniformización, porque justamente el principio de universalización es extrínseco a las culturas 11 . Este principio llevará a una crítica radical del sistema capitalista como inmoral: "No se niega que tal tipo de civilización, vigente tanto en el este como en el oeste y que debe llamarse civilización capitalista — sea capitalismo de Estado o capitalismo privado - ha traído bienes a la humanidad, que como tales bienes deben ser conservados y propiciados [...] Pero visto el problema en su totalidad mundial desde la perspectiva de las necesidades reales y de las expectativas de la mayor parte de la población mundial, esa civilización de la riqueza y del capital ha de ser superada radicalmente"12. Ellacuría propone una civilización que garantice de modo estable las necesidades básicas y las posibilidades de personalización. Ya en el terreno económico político, propone un modelo que supere tanto los límites del capitalismo liberal como del centralismo de Estado marxista. Fundamentalmente se trataría de un socialismo democrático con acciones y organiza-

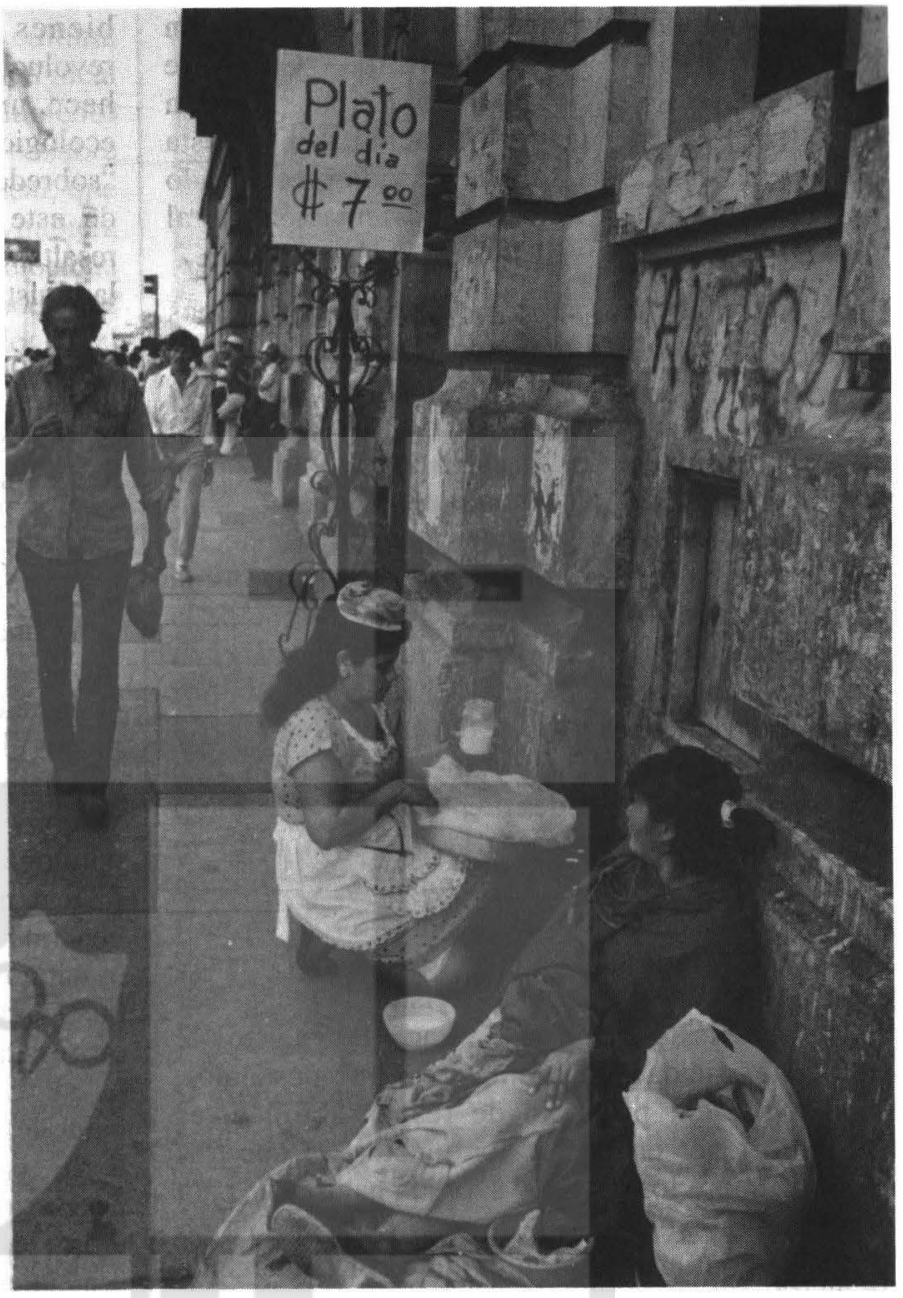
ciones comunitarias y con una efectiva democracia en las empresas 13 . No se hace muchas ilusiones, dada la persistencia de la guerra fría cuando escribe el artículo, de que este modelo pueda darse, pero quizás hoy estamos paradójicamente en mejores condiciones para propiciar este

orden y de comprender el pensamiento social de Ignacio Ellacuría 14. Lo que me interesa aquí recalcar es que este principio, muy fecundo, pues en él reposa toda la crítica de Ellacuría, no lo justifica de manera radical. ¿Se trata de la asunción

10. I. Ellacuría, “Utopía y profetismo desde América Latina", Revista Latinoamericana de Teología 17 (1989), p. 153.

11. Ibid., p. 156.

12. Ibid, p. 170.

13. Fijémonos que la democracia liberal es democracia representativa y no admite ninguna forma de participación directa de los gobernados en los procesos de gobiemo. En el área de la produccion, el trabajador no deja de ser mercancia en los parses ricos. Mercancía muy bien cuidada por cierto, mientras es maltratada y desechada como tal en los países pobres.

14. Es interesante a este respecto el debate contemporáneo entre una socialdemocracia mundial que atemperara los efectos más perniciosos del sistema económico vigente, preconizada por Giddens como lo más deseable dentro de lo que podemos considerar políticamente factible (Véase A. Giddens, Más allá de la izquierda y la derecha. 
de un elemento de pensamiento de Kant en un planteamiento filosófico distinto? ¿Cómo se articularía este recurso kantiano con su reflexión filosófica? ¿Tiene una justificación radical esta universabilidad de las formas de vida preconizado por Ellacuría como criterio de orientación moral última?

En el Principio de responsabilidad de Hans Jonás encontramos dificultades parecidas a las de I. Ellacuría. No podemos más que suscribir buena parte del enfoque y análisis de Hans Jonás: "Hasta ahora, la reflexión ética se ha concentrado en la cualidad moral del acto momentáneo mismo. Ninguna ética anterior tuvo que tener en cuenta las condiciones globales de la vida humana ni la existencia misma de la especie. Bajo el signo de la tecnología, la ecología, el mercado mundial y, en definitiva, los procesos de mundialización, la ética tiene que ver con acciones de un alcance causal que carece de precedentes y que afecta al futuro, a ello se añaden capacidades de predicción, necesariamente incompletas pero que superan todo lo anterior"15. La existencia del planeta, la duración de la vida, el aumento de la duración de la vida humana, la configuración genética del ser humano, cada vez pende más de una decisión humana. Por tanto, una ética que pueda servimos de orientación, ante las capacidades extremas que hoy poseemos, debe partir del principio de responsabilidad, es decir, de tener en cuenta los efectos de nuestras acciones sobre los demás y sobre la naturaleza para preservar la existencia de la vida humana. Ya no podemos confiar más en ninguna razón inmanente en la historia, y si lo hiciéramos, sería una imprudencia absoluta.

También la proyección política de su ética se acerca más a algunos de los análisis mesoamericanos. En lugar de países desarrollados hablará de países "sobredesarrollados" y de la incorporación de la clase asalariada de estos países a la pervivencia de un sistema que les permite mantener bienes materiales apenas soñados por los revolucionarios del siglo XIX. Sin embargo, Jonás hace un análisis en términos de un sistema ecológico mundial puesto en peligro por los países "sobredesarrollados", sin reparar en la imbricación de este sobredesarrollo con el subdesarrollo, y resaltando mucho más la desarmonía ecológica que la injusticia.

Ahora bien, en nuestro tema lo que nos interesa destacar es que el principio de responsabilidad de H. Jonás, por el cual el imperativo de que haya una humanidad y de perseverar en el ser es nuestro primer deber, se fundamenta en una ontología o metafísica más o menos aristotélica, que no es obvia o evidente sin más. La naturaleza labora hacia algo, tiene fines, y ello constituiría un bien absoluto, una fundamental autoafirmación del ser, un sí en contra de la nada. "Que al ser hay algo que le importa - al menos él mismo - es lo primero que sobre él puede enseñamos la presencia en él de fines"16. La ética se convierte, en H. Jonás, en un capítulo de la ontología. Frente a la acusación de incurrir en una falacia naturalista, es decir, de partir del ser en general para fundamentar un deber $y$ de pensar que la naturaleza confiere autoridad, $\mathbf{H}$. Jonás afirmará que los que hablan de falacia naturalista mantienen otra metafísica, una metafísica dualista, mediante la cual pueden disentir legítimamente de la naturaleza al invocar una instancia externa a ella17. Pero, ¿para defender uno u otro principio ético es necesario implícita o explícitamente profesar una u otra teoría metafísica? o, acaso, ¿no sería posible fundamentar la ética en una filosofía primera y radical más allá o más acá de toda construcción metafísica?

Enrique Dussel, siguiendo a Levinás y polemizando con Apel y las éticas discursivas, insistirá en que la verdadera universalidad se alcanza si atendemos a la alteridad $u$ exterioridad inscrita en la sensibilidad humana previa a cualquier registro

El futuro de las políticas radicales, Cátedra, 1996.) y la democracia económica o cooperativa, esto es, que los trabajadores tengan un control efectivo sobre los beneficios propiciada por David Schweickart como un modelo capaz de enfrentar los retos ecológicos actuales, optimizar la producción y racionalizar la economía (Véase D. Sweickart, Against Capitalism. Cambridge, 1996). Ambos autores dibujan las posibilidades de transición a este nuevo orden económico polftico. Pero mientras Giddens considera el modelo de David Sweickart inviable, éste considera la alternativa de Giddens insuficiente.

15. H. Jonás, El principio de responsabilidad, Barcelona, 1995, p. 16.

16. Ibid., p. 145.

17. Ibid., p. 139. 
lingüístico. De ese modo, el bien de una cultura, de una totalidad $o$, incluso, de una comunidad ideal de comunicación, no puede ser el fundamento último de la moralidad de los actos, porque encubre al otro. Es imposible, aún en un acuerdo ideal, que no haya "otros" excluidos. "Para que no los hubiera necesitaríamos una inteligencia infinita de velocidad infinita para descubrirlos. Y aún así no podemos tener conciencia de todos los otros excluidos en el presente que serán descubiertos como excluidos en el futuro"18. El esfuerzo ético fundamental para Dussel es el de tornar visible al otro excluido, a aquel que incluso en un consenso ideal hemos vuelto invisible. La diferencia esencial entre la ética del discurso y la ética de la liberación se juega en su punto de partida mismo. La primera parte de la comunidad de comunicación, la segunda de los excluidos de esta comunidad. Si en las éticas del discurso echamos en falta una mayor radicalidad en el punto de partida (hay una comunicación física previa a todo acto lingüístico), la principal dificultad que se halla en Dussel es que el principio de exclusión, el descubrimiento del otro como el afectado en la exterioridad, como el permanentemente excluido de la totalidad, sea cual sea ésta (consenso, cultura, sistema), más parece fruto de una tradición, la tradición judeocristiana, que de una justificación filosófica radical 19 . Tanto Dussel como Ellacuría nos brindan dos magníficos principios para la perspectiva del oprimido: el principio de universalización fáctica y el principio de exclusión. No dudamos de las virtualidades de su aplicación pero, más allá del propio interés moral de los autores, no encontramos una justificación filosófica última de estos principios.

\section{La universalidad fáctica}

A partir de los datos que nos ofrecen diferentes ciencias, fundamentalmente la sociología y la ecología, podemos afirmar que la universalidad no se refiere sólo a la existencia de sistemas globales, ni a ninguna utopía ilustrada, ni siquiera a la idea de que todos los seres humanos compartimos una estructura racional o genética parecida, sino a algo mucho más elemental, a la vertebración y estructuración mundial de los actos humanos más simples y anodinos, a la transformación de contextos locales

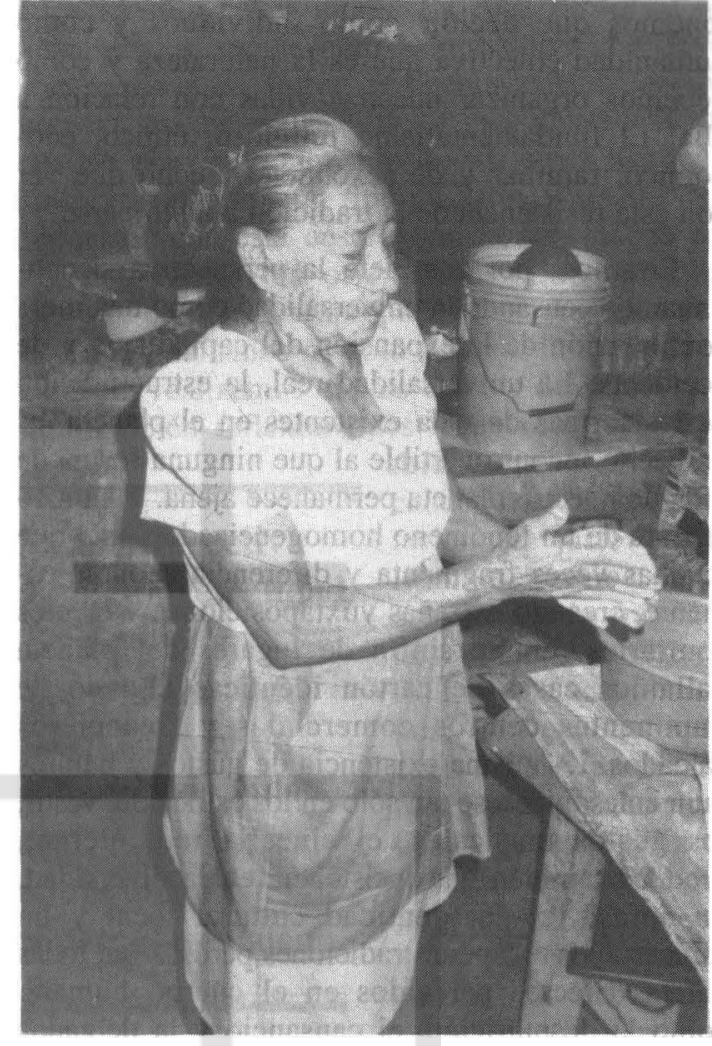

e incluso personales e íntimos en contextos mundiales. Nuestras actividades cotidianas están decisivamente influidas por sucesos que ocurren al otro lado del mundo. Y a la inversa, los hábitos de vida locales han adquirido consecuencias universales. La decisión de comprar cierto producto tiene repercusiones no sólo en la división internacional del trabajo sino en los ecosistemas terrestres. En este orden social mundial las tradiciones pierden fuerza, se les exigen explicaciones y motivos. La destradicionalización converge con la desaparición de la naturaleza como entorno físico independiente de la actividad humana20. Los problemas de degradación medioambiental que nos perturban proceden precisamente de la transformación de lo natural en lo social y cultural. Por consiguiente, la apelación a lo natural tiene hoy menos interés ético que nunca. Que sea más natural una mujer con veinte partos que una sin gestación no significa que lo primero sea preferible. Hoy

18. E. Dussel, "Etica de la liberación desde los pobres y excluidos", Evangelio y liberación, Madrid, 1994, p. 81.

19. Véase aqứ el libro de próxima publicación de Antonio González, Filosofía primera.

20. A. Giddens, Más allá de la izquierda y la derecha, el futuro de las políticas radicales, Cátedra, 1996, p. 56 y ss. 
tenemos que decidir como individuos y como humanidad colectiva qué es la naturaleza y como debemos organizar nuestras vidas con relación a ella. El fundamentalismo religioso, étnico, económico, familiar y de sexo tiene mucho que ver con esta resistencia de la tradición a justificarse.

Erramos por completo la perspectiva si continuamos pensando la universalidad como una mera continuación de la expansión del capitalismo y de occidente. La universalidad real, la estructuración de las formas de vida existentes en el planeta, es un hecho incontrovertible al que ninguna forma de vida de nuestro planeta permanece ajena. Tampoco se trata de un fenómeno homogeneizador, sino que muchas veces fragmenta y diferencia económicamente, creando extrañas yuxtaposiciones y efectos contrarios: en un sinfín de lugares del planeta hallamos casas de cartón idénticas al lado de imponentes centros comerciales y financieros calcados. La misma existencia de gustos y hábitos mundiales, piénsese tan sólo en los estilos del vestir, los gustos musicales, el cine, la red internet, produce también una insistencia en la diversidad, un énfasis en la identidad cultural local y un esfuerzo por recuperar tradiciones perdidas en todas partes. Efectos parecidos en el cuerpo humano como la desnutrición, el cansancio y la delgadez tienen en nuestra sociedad mundial orígenes completamente diversos. Mientras el anoréxico se muere de hambre en un mar de abundancia donde, al disponerse de enormes cantidades de alimentos, todos están hasta cierto punto a dieta, pues tienen que elegir permanentemente para comer y decidir como ser respecto al propio cuerpo, el hambriento se muere de hambre, porque no se le deja nada para llevarse a la boca21.

De alguna manera somos la primera generación que vive en un orden cosmopolita universal, en un mundo en el que no hay alteridades radicales, otros no afectados por mi acción, donde todos compartimos intereses y riesgos comunes, más allá de la conciencia que tengamos de ello y del juicio moral que nos merezca. Muchos de estos riesgos (desastres nucleares, ecológicos) están alejados del control no sólo de las personas, sino también de las grandes organizaciones y de los estados. Son riesgos con los que tendrán que convivir toda la humanidad y todas las culturas responsable $y$ permanentemente, pues aún destruyendo, por ejemplo, todas las armas nucleares, el armamento podrá ser reconstruido en cualquier momento22. Las tradiciones no dejan de existir, ni de tener relevancia e interés para orientar la acción, pero se nota más su insuficiencia, desde el momento en que todo lo que solía ser natural o tradicional tiene que ser objeto de elección y decisión. En cualquier caso, al ponerse las tradiciones en contacto unas con otras, se ven forzadas a justificarse permanentemente y no podemos ya tomar decisiones sin una reflexión sobre las consecuencias de la propia acción. Las consecuencias de la acción son mucho más relevantes hoy para el juicio moral que la apelación a cualquier tipo de valor tradicional.

Claro está que estas constataciones, de hecho no nos sirven para predecir el futuro. Nada impide que puedan aparecer nuevos totalitarismos, la desintegración de los ecosistemas del mundo o la conversión a los países ricos en naciones amuralladas. Pero no son irrelevantes para orientar nuestra acción ni para ejercer una crítica ética y política del momento presente. Desde estos datos, llama mucho la atención el doble rasero con que se miden los derechos de las personas y sus actos. Mientras el crecimiento de la población es tenido por muchos gobiernos y ciudadanos del mundo como causa grave de deterioro del medio ambiental, el aumento del consumo, que deteriora más el ambiente que el propio crecimiento de la población, se juzga casi universalmente como un bien, y es, de hecho, el objetivo fundamental de las políticas económicas nacionales. Los parses ricos mantienen una transferencia directa de riquezas, una especie de caridad técnica con los países pobres, pero se niegan, en cambio, a trasladar y ofrecer las mismas posibilidades de empleo y educación que otorgan a sus ciudadanos, a los ciudadanos de los países pobres. Mientras los paŕses ricos subvencionan campañas antinatalistas en el sur, promueven campañas natalistas en el norte. $Y$ así podríamos seguir con una enumeración inacabable. En conclusión, si hoy constituimos una única sociedad mundial, los derechos y valores más anodinos de la ética política que rigen en el interior de los estados son exigibles mundialmente y la aspiración a una ciudadanía mundial es menos una utopía que un derecho escamoteado a las grandes mayorías de la humanidad.

21. A. Giddens. Ibid., p. 90.

22. A. Giddens. Las consecuencias de la modernidad, 1994. 
Recapitulando lo dicho hasta aquí, nos encontramos con una universalidad de facto y con la insatisfacción de los planteamientos éticos universalistas elaborados hasta ahora por dar por supuesto alguna teoría, por la sospecha de que constituyen un particularismo disfrazado, por depender de una determinada tradición, o por no gozar de una fundamentación firme. $Y$ por otro lado, con toda la verdad que tienen las críticas relativistas, son en el presente, por los avatares de la historia, insostenibles en su esencia. Hay una respectividad, funcionalidad o afectación de todos los seres humanos entre sí que cuestiona toda afirmación de solipsismo e inconmensurabilidad cultural. Quizás hoy, por el mismo hecho de adquirir conciencia de la estructuración mundial de las formas de vida planetaria, estemos en una situación privilegiada para intentar una verdadera fundamentación ética universal, esto es, válida para cualquiera y no proclive a la exaltación de una forma de vida concreta. Lejos de ver en nuestra época la desaparición de unos valores universales, ésta es, quizás, la primera ocasión en la historia de la humanidad en la que dichos valores pueden salir adelante.

\section{La ética como análisis de la acción humana}

Lo primero que deberíamos hacer en este nuevo contexto es replantearnos el estatuto mismo de la ética filosófica. ¿Cuál es su objeto? ¿Cuál es su pretensión? No es una cuestión nada fácil. Algunos como Zubiri23 identifican ética con moral, otros con normatividad y obligatoriedad, otros con el estudio de determinados actos morales, aquellos de los que somos conscientes y podríamos continuar con una larga enumeración. Desde Kant se suele asociar la ética con lo normativo, con el deber ser, pero esto es ya dar mucho por supuesto. Creo que aquí es importante distinguir claramente entre la ética filosófica y la moral. La ética filosófica no tiene porque ser de entrada normativa. Le basta con analizar en forma pormenorizada la acción humana misma y describir lo más ajustadamente posible el comportamiento de los seres humanos sin privilegiar ningún tipo de actos y sin dar por supuesto que esta descripción no nos pueda dar algunos elementos orientativos. La moral, en cambio, consiste en apropiación de posibilidades. Los seres humanos no sólo actuamos moralmente, es decir, realizamos ciertos actos y no otros, sino que también reflexionamos sobre este comportamiento práctico, buscando una cierta orientación. Es justo lo que llamamos ética. Este estudio puede fragmentarse y fijarse en diferentes tipos de actos humanos. De ese modo, la ética ecológica reflexionará sobre los actos que tienen que ver prioritariamente con la naturaleza; la bioética sobre los actos que tienen que ver con la vida humana, su inicio, su preservación y su final; la ética sexual sobre las prácticas sexo-eróticas y un largo etcétera. También pueden estudiarse los actos más o menos estandarizados en unas determinadas instituciones y profesiones: ética empresarial, ética médica, ética familiar... .

Muchas ciencias aportan conocimientos valiosísimos para la reflexión sobre los actos y la búsqueda de orientación. Así, la psicología nos muestra las motivaciones internas de la conducta del individuo, la estructura del carácter y la personalidad. La antropología social y la sociología, las estructuras en las que se integran las relaciones humanas. El historiador, el carácter cambiante de la moral. En general, las diferentes ciencias nos muestran el cambio contínuo en la conducta humana y de las normas mismas por las cuales esta conducta es juzgada. Sin embargo, la ética filosofica no constituye ni un compendio de las diferentes éticas regionales, ni una suma de los saberes sobre

23. Zubiri suele identificar la ética con un sistema de valores. Véase nota en X. Zubiri. Sobre el hombre, 1986, p. 413. Por eso no cejará de repetir en Sobre el sentimiento y la volición, 1992, que los asuntos de ética no le competen. 
la acción humana de las diferentes ciencias. La ética filosófica busca, en primer lugar, determinar qué es lo específicamente moral, en qué consiste la esencia de la moral y no tiene por qué adherirse a una posición moral concreta. Su misión es mucho más amplia que explicar la moral concreta u abogar por una u otra moralidad. Es precisamente en la medida en que la ética filosófica se libera de la moral, de las morales efectivas ya dadas en las que siempre estamos, que puede ser más útil para orientarnos en forma mínima. En segundo lugar, la ética filosófica no pretende ser una teoría, investigación o explicación de los actos humanos, sino una descripción y análisis de los mismos, todo lo abierto y provisional que se quiera, pero accesible para todos $y$, en este sentido, rigurosamente universal.

La moral, entendida como apropiación de posibilidades, conlleva en el límite que hay tantas morales como seres humanos, porque es imposible que haya una apropiación idéntica de posibilidades, pero eso no significa que esta apropiación de posibilidades no se estructure de manera sistemática según la posición social, el momento histórico y múltiples mecanismos psico-sociales. Esta moral efectiva, consistente en la constancia con la que repetimos unos determinados actos, está permanentemente ensamblado con un cuerpo de tabúes, normas, valores y reglas que estructuran en forma interna la acción. Se podría objetar que las posibilidades son apropiadas socialmente o que, en último término, son decididas por la constitución psicológica del individuo pero esto, en todo caso, son explicaciones discutibles del hecho incontrovertible de que el ser humano, por uno u otro mecanismo, se apropia de posibilidades 24 . Lo que constituye la moral no es la realización de unas determinadas posibilidades, la asunción de unos determinados contenidos, sino el mero hecho de tener que apropiarme de alguna posibilidad para subsistir. Exceptuando quizás algunos actos reflejos, toda actividad humana tiene un carácter moral. Hay moral allí donde se da este dinamismo de apropiación de posibilidades. Este dinamismo de apropiación de posibilidades es el objeto de la ética.

\section{Etica y filosofia primera}

Se ha insistido en pensar la ética como un capítulo de la filosofía, como una extensión adscrita a alguna filosofía segunda, derivada de una teoría antropológica o de una teoría metafísica. Levinás y Dussel afirmarán que el punto de partida de toda reflexión filosófica es la ética, que la filosofía primera es justamente ética. Antonio González25 justificará desde el punto de vista filosófico esta afirmación de Dussel. No se trata de convertir la ética en filosofía primera por alguna consideración moralizante o extrínseca a los propios resultados del análisis filosófico, ni de hacer ver la importancia decisiva de la filosofía primera para la reflexión ética, sino de mostrar paladinamente que el punto de partida radical del análisis, el hecho inconcuso, es la acción humana y que, por tanto, la ética primera y la filosofía primera coinciden en su objeto. Ni por razón de método, ni por razón de objeto se podrá distinguir entre ambas, si acaso sólo por el interés que guía la investigación. Mientras la ética primera busca desprender en el análisis de lo inmediatamente actualizado en aprehensión alguna orientación para la acción humana, la filosofía primera pone entre paréntesis este mismo interés. Este interés es el que nos permite diferenciar también entre una filosofía primera y una antropología y una sociología primera26.

La gran ventaja que nos ofrece este punto de partida es que no necesitamos dar ningún rodeo por alguna teoría científica para la fundamentación

24.. "Lo moral está constituido por el sistema de propiedades que tiene el hombre por apropiación", X. Zubiri, Sobre el hombre, Madrid, 1979, p. 374.

25. A. González, Filosofía primera, de próxima publicación.

26. Aunque en un sentido diferente del que tiene la antropología primera para Ellacurfa. Véase "Introducción crítica a la antropologfa de Zubiri", Realitas II, 1975. La antropología primera en Ellacuría se constituye mediante el paso de la consideración talitativa de la realidad humana a su consideración trascendental, en nuestro caso, siguiendo a Antonio González, con la descripción de la realidad humana actualizada en la aprehensión. Tampoco coincidiŕa la ética primera con la protomoral de Diego Gracia, pues como veremos, tan relevante es para la fundamentación ética, el análisis de la aprehensión primordial, del logos y de la razón y no tenemos por qué privilegiar el primero de estos momentos. Véase D. Gracia, Fundamentos de bioética, Madrid, 1992, p. 367 ss. 
ética, que la acción tiene una inmediatez que no tiene el lenguaje $y$ es accesible para cualquiera, no depende de una determinada cultura, de unas determinadas instituciones, o de una determinada forma de vida. No hay tampoco aquí ningún recurso idealista, no se da por supuesta ninguna entidad que rija los procesos y desde la cual se valore.

$\mathrm{Al}$ intento de elaboración de una ética o filosofía primera como análisis de los actos humanos se le pueden contraponer muchas tesis, pero hay en particular tres que nos hacen dudar de nuestro intento. La primera, que ha cobrado gran relevancia en la filosofía de la ciencia27, nos dice que las observaciones, los hechos están cargados siempre de teoría. Lo que percibimos depende en alguna medida de la teoría que sostenemos, consciente o inconscientemente. Con lo cual se negaría todo intento de filosofía primera o ésta no sería más que una defensa encubierta de una determinada teoría. La segunda afirma que hay una prioridad de los actos aprehensivos, intelectivos, sobre los afectivos y los volitivos 28 . Y la tercera tesis sostiene que en el análisis de lo inmediatamente dado en la aprehensión, sin deslizarnos hacia ningún sujeto o sustancia que esté debajo de los actos, tenemos como dato primordial un momento consciente $y$, en consecuencia, una primariedad de la subjetividad e intimidad, respecto a los demás y a las cosas. Las dos últimas tesis no niegan propiamente la posibilidad de una filosofía primera, pero sí que la ética se identifique con ella. Para contestar con propiedad cada una de estas tesis deberíamos escribir largos tratados filosóficos, aquí sólo esbozaremos unas líneas de respuesta.

Respecto a la primera tesis, Antonio González ha mostrado con contundencia que aunque el sentido de lo que vemos varíe según las culturas, la posición social y las experiencias pasadas, y que aunque el sistema de propiedades mismo de lo

actualizado en aprehensión esté organizado como tal sistema de propiedades, en virtud de los conceptos o la misma fisiología que estructura en cada uno sus percepciones 29 , la pluralidad de sistemas de propiedades actualizados en nuestra aprehensión es mucho menor que la pluralidad de sentidos. Mientras en el análisis y la descripción de lo actualizado en aprehensión es posible un acuerdo y un avance transcultural, el acuerdo sobre el sentido es prácticamente imposible si no se comparte una misma cultura. La primera tesis, por tanto, no niega el método analítico de una filosofía

27. G. Fourez, La construcción del conocimiento científico, 1992.

28. A. Pintor-Ramos, Realidad y sentido, Salamanca, 1993, pp. 89-98.

29. El ejemplo que pone Antonio González es muy ilustrativo. Los aztecas al ver los primeros caballos no distinguían el caballo del jinete. 
primera que pretenda dar cuenta de lo inmediatamente actualizado en la aprehensión, eliminando aquellos presupuestos que lo impidan. Sin embargo, de algún modo limita las pretensiones de un análisis que pudiera aspirar a una descripción pura. Está claro que el análisis está cargado de teoría, pero mientras el análisis pretende describir lo actualizado en nuestros actos, la teoría pretende explicarlo. Mientras el análisis pretende describir mejor o peor el sistema de propiedades actualizado en aprehensión, la teoría tratará de explicar por qué se actualizan diferentes sistemas en fisiologías diferentes o aun en culturas diferentes.

Respecto a la tesis que afirma una prioridad de los actos aprehensivos, hay que destacar que el análisis no puede llegar a establecer ninguna prioridad de la sensación sobre la afección y la volición, ni tampoco ningún tipo de relación causal entre los diversos actos de modo que se pudiera priorizar algunos de ellos. Lo que encontramos en el análisis es una dependencia funcional de todos los actos humanos. Del mismo modo que una sensación causa una determinada afección y volición, una afección y una volición crean una determinada sensación. Toda sensación, afección y volición son irrepetibles $e$ indescriptibles en todas sus riquezas y matices, pero coinciden al menos en su apertura y alteridad radical. Sólo un prejuicio intelectualista puede privilegiar algún tipo de actos.

En cuanto a la última tesis hay que observar que hay muchos actos humanos que no son conscientes, que no se actualizan ante sí mismos.
Es más, la mayor parte de nuestras acciones transcurre en un plano preconsciente. Hace un momento escribía, pero no tenía conciencia de estar escribiendo, no me daba cuenta ni de mi mano, ni de las líneas, estaba más bien inmerso en ideas tumultuosas que quería expresar de manera ordenada. Aceptando el sentido restringido de conciencia como "darse cuenta", se podría argüir que todos los actos humanos susceptibles de ser analizados en una filosofía primera tienen una referencia inmediata a mí, tienen un carácter personal, sean estos conscientes o no. ¿En qué consiste este mi, este carácter personal que tienen los actos humanos? Todo lo sentido en nuestros actos se presenta siempre como algo radicalmente otro que el acto mismo. Esta autonomía radical o distensión de los actos que integran la acción constituye el carácter personal e íntimo más elemental de los actos humanos. Por este carácter, yo puedo sentir los actos como míos y los otros se entreverán en mis acciones, tenga conciencia o no de ello. No hay ninguna primariedad de la conciencia sobre lo social, ni del mi sobre los otros, ni de la interioridad sobre la exterioridad30. Mismidad y otreidad son radicalmente congéneres. Sin una enajenación ${ }^{31}$ constitutiva no habría persona, sin distensión no habría socialidad.

Admitida entonces la posibilidad de una filosofía primera y que ésta consiste en el análisis de los actos humanos, sin privilegiar de algunos de ellos, podríamos preguntarnos todavía qué encontramos en ello que sea tan importante para una ética filosófica. En principio, parece claro que

30. "Todas las cosas actualizadas son radicalmente otras respecto al acto en que se actualizan. Me siento a mí mismo como otro entre otros. Mi cuerpo, mi mano, se actualiza en la misma alteridad en la que se actualizan las demás cosas, tanto personales como impersonales". A. González, apuntes filosofía primera.

31. Aquí el termino enajenación se ha liberado de todo presupuesto hegeliano. La enajenación es la permanente actualización de los demás en mis acciones, no un estadio. En gran parte de la tradición marxista, la noción de alienación presupone una noción de una esencia humana universal con unas potencialidades permanentes, cuya realización es negada. La enajenación es pensada como un fenomeno enteramente negativo, opuesto al de la realización humana. 


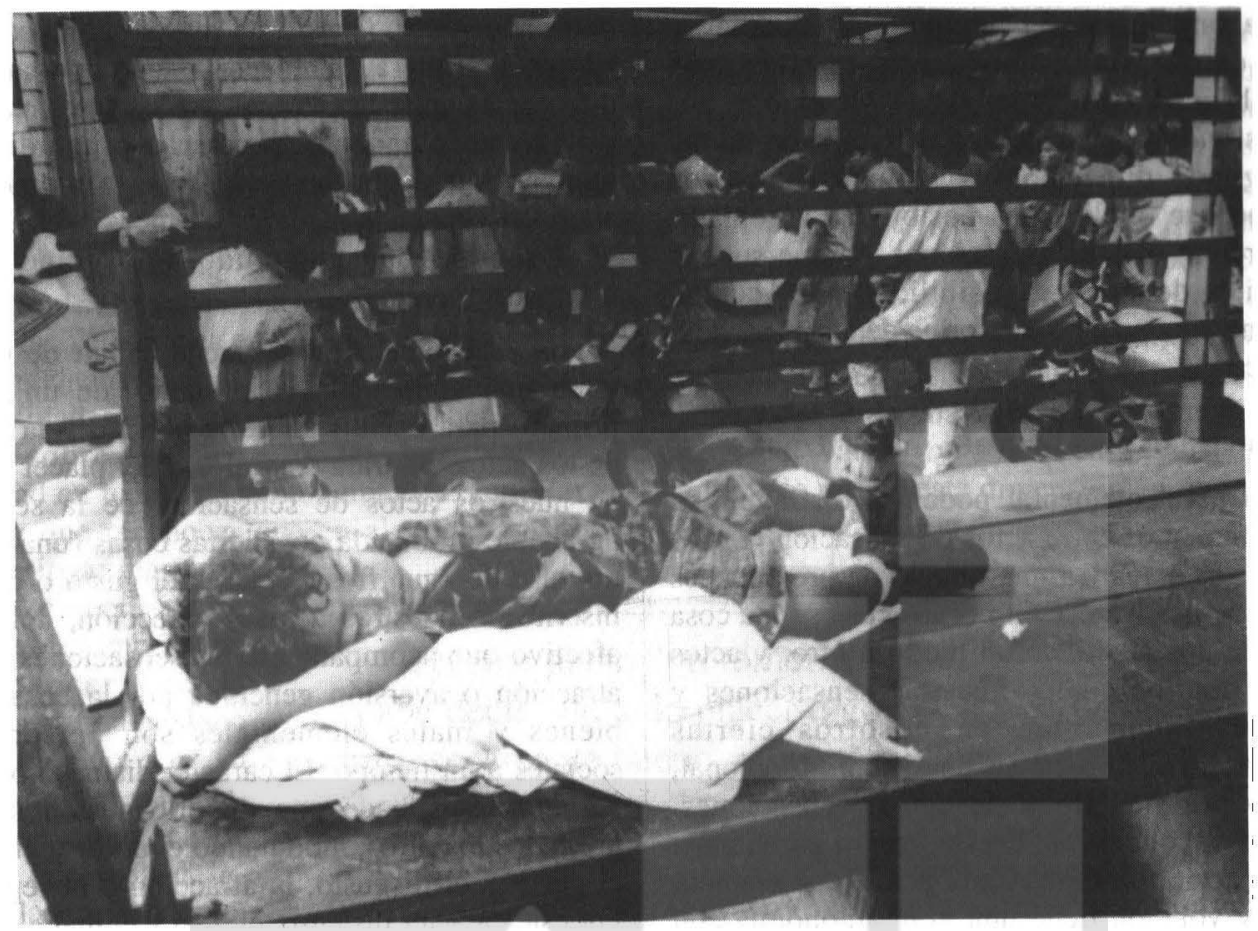

la vía analítica es mucho más acotada que la vía teórica, no existe el mismo grado de apertura en la explicación de los actos humanos que en su descripción. Tampoco es todo interpretación, o en todo caso, hay "interpretaciones" que no dependen de las construcciones teóricas, de las creencias y opiniones de cada cual, sino que están contrastadas por algo inmediatamente dado que podemos esforzarnos por describir. Esto por sí solo ya sería decisivo en ética, porque si en antropología hay tantas morales como culturas, en filosofía encontramos tantas éticas como teorías metafísicas y epistemológicas y aquí precisamente prescindiríamos de toda teoría metafísica ${ }^{32}$. La gran ventaja de enraizar la reflexión ética en la filosofía primera es que no se apela a ninguna teoría científica, histórica, social, antropológica, o metafísica, y por ello la ética filosófica puede pretender una auténtica universalidad.
Hemos definido la moral como apropiación de posibilidades. Toda actuación humana es moral en la medida en que implica una apropiación de posibilidades, en la medida en que no es unívoca y que no está prefijada, como en el animal, por un sistema estimúlico. Otra cosa es que la posibilidad apropiada sea consciente o inconsciente, determinada por mi grupo social o por grupos sociales desconocidos. El que un acto sea moral no pende de nada exterior al acto mismo, sino de la propia apertura e indeterminación de los actos humanos. En el límite sólo quizás algunos actos reflejos son en el ser humano actos amorales33. Cada uno de nuestros actos es a su vez un acto moral. Ahora bien, desde una ética filosófica es legítimo deslindar tres dimensiones de la moral o apropiación de posibilidades. Estas dimensiones siguen la distinción establecida por Antonio González entre acción, actuación y actividad34. A la primera dimen-

32. Aun las éticas neokantianas son solidarias de algún tipo de metafísica que establece un hiato entre un mundo moral autónomo y la sensibilidad. Así, Adela Cortina pensará que el tipo de análisis que aquí proponemos puede aportar complementos interesantísimos a la reflexión ética, pero que permanece siempre tangencial al hecho ético o moral. Véase Adela Cortina, Etica sin moral, 1990, p. 68 y ss.

33. Véase en Martín Baró la dificultad para establecer una línea divisoria clara entre actos aconductuales y actos conductuales. Martín Baró, Acción e ideología. Psicología social desde Centroamérica, p. 53.

34. A. González, Filosofía primera. 
sión la llamaré dimensión "protomoral", atendiendo al hecho de que, sin ser moral, esto es, contar con una posibilidad apropiada, incoa ya el que nos tengamos que apropiar de una determinada moral. A la segunda dimensión la llamaré dimensión fáctica, porque implica una posibilidad apropiada, y a la tercera, dimensión racional, porque supone apropiación de nuevas posibilidades o, cuanto menos, una ponderación o reforma de las posibilidades existentes.

\section{La dimensión protomoral}

En un nivel elemental podemos distinguir en los actos humanos entre actos de sensación por los cuales se nos actualiza una unidad de propiedades sensibles, actos de afección por los cuales toda cosa actualizada nos afecta de un modo u otro, y actos volitivos por los cuales nuestras sensaciones y afecciones determinan en nosotros ciertas voliciones. La acción es así un sistema funcional, integrado por tres tipos de actos: sensaciones, afecciones y voliciones. $Y$ esta acción es humana si es una acción abierta. Cada acto de sensación, afección y volición tiene una gran autonomía con respecto al otro. Cada afección puede formar sistema con una sensación y una volición muy variada. Hay una autonomía radical de las tres que no encontramos en la acción animal pero nunca se rompe la funcionalidad de los tres tipos de actos.

Es importante destacar que los actos tomados en tanto que acciones, es decir, como sistema funcional de actos sin entrar en la consideración de una u otra actuación concreta, presentan un carácter protomoral por el simple hecho de su apertura y distensión, por no estar instintualmente determinados. Debido a esta distensión de los actos es imprescindible que la acción se estructure mediante actos intencionales, pero la acción no es elementalmente personal ni moral por tener estos actos, sino por la pura apertura. Aun en el caso hipotético de un niño lobo35 o niños salvajes, cuyos actos intencionales fueran los de una cultura lobuna y que, en consecuencia, no actuaran humanamente, no perderían el carácter personal ni moral elemental de sus acciones. Claro está que no compete a una filosofía primera establecer o dar por supuestas diferencias entre los animales y los seres humanos, pero en cualquier caso, el carácter primordial de lo humano habrá que buscarlo en este momento de alteridad y no en la razón, la conciencia, el lenguaje, y el sentido aun entendido sólo como acción orientada.

En esta dimensión se puede hablar de un bien $y$ un mal elemental y, por tanto, de un criterio primero para decidir sobre la bondad y la maldad de los actos. Se trata del dolor o del placer inscrito en nuestros actos de sensación, de la sensación agradable producida por ciertas cosas (una caricia, un vaso de agua fresca, etc.), del gusto o disgusto inscrito en nuestros actos de afección, del estado afectivo que acompaña ciertas sensaciones y de la atracción o aversión generada por la cosa. Estos bienes y males elementales son personales y sociales a un tiempo. El carácter distenso personal de mis actos hace que en ellos estén siempre presentes los otros, modulando el dolor y el placer, el gusto y el disgusto, la atracción y la repulsión. Por este carácter distenso, el bien y el mal elemental aparecen sólo en la acción humana. El animal tiene daños, y hay cosas que humanamente consideramos nocivas para el animal, pero no bienes y males elementales, en la medida en que el animal no tiene esta constitutiva apertura y alteridad en sus actos 36 . $\mathrm{O}$, dicho de otro modo, el dolor o placer, el gusto o disgusto, la versión o aversión de la acción sólo tiene sentido tipificarla como bien o mal elemental cuando la acción es abierta. Sin esta constitutiva apertura, el dolor y el placer constituirían un puro estado tónico o vital, ajeno a toda apropiación de posibilidades, a toda moralidad.

Aquí habría que recoger el momento de verdad de las tesis hedonistas, emotivistas y utilitaristas, despojándolas de toda su metafísica implícita. En la fílosofía griega, los cirenaicos y los epicúreos dieron una gran importancia a la satisfacción de los placeres, los gustos y los deseos como criterio de una buena vida. En el utilitarismo, la noción del cálculo hedonista se convirtió en el fundamento

35. Véase la documentación al respecto de Martín Baró, lbíd., p. 128 ss. Lo que parecen revelar estos estudios, con toda la provisionalidad de los mismos, es que después de una determinada edad es imposible que la acción humana adquiera esquemas intencionales humanos. De verificarse esta cuestión podráamos decir que el niño salvaje es accionalmente humano, aun cuando no llegue a actuar en forma humana.

36. X. Zubiri, Sobre el sentimiento y la volición, Madrid, 1993, p. 259. 
de la filosofía política. La buena sociedad es aquella que maximiza la mayor felicidad para el número más grande. Sería muy artificioso no reconocer una gran parte de verdad en todas estas éticas. Se podría hablar aquí de unas necesidades elementales, de un umbral mínimo como comer, dormir, beber, respirar, deseo sexual, compañía, afecto, sin la satisfacción del cual no hay moral posible. Claro está que las variaciones en las maneras de satisfacer estas tendencias básicas parecen amplísimas, que las necesidades son históricas y que caben muchas teorías sobre las necesidades básicas ${ }^{37}$. La forzosidad en toda tendencia humana es muy laxa, pero hay que reconocer que en algunos umbrales es imperiosa: hambre, respirar, comer, afecto mínimo... Lo importante es reconocer que la moral no es el abandono de lo biológico, sino su integración 38 . La fundamentación biológica de la ética que realizó Ignacio Ellacuría 39 adquiere aquí todo su vigor. No se trata sólo de que no se puedan ignorar la presencia de los dinamismos animales en el ser humano, sino de ver que, por su apertura, estos dinamismos dejan de ser dinamismos animales.

En este plano "protomoral" cabe decir que todo placer o gozo es intrínsecamente bueno, que una acción es elementalmente buena cuando produce placer, gusto y atracción a los demás y a mí mismo y elementalmente mala cuando produce dolor, disgusto y repulsión. Al no considerar la moral como una dimensión superior, espiritual o añadida a la acción humana, como si la acción sin conciencia o sin lenguaje fuera una acción animal, el hambre, la enfermedad, la miseria, el acceso a los bienes materiales pasan al primer plano de la consideración moral. De hecho, en la suma de bienes y males elementales se juega la partida más decisiva de la moralidad humana. Si bien una suma de placeres elementales no constituye necesariamente una actuación buena, considérese sólo el placer que nos puede producir la venganza, no es pensable ninguna actuación buena que no genere bienes elementales. Valores culturales extraordinarios como la democracia, el diálogo y el consenso pueden ser altamente maléficos si, de hecho, se fundamentan en instituciones que producen males elementales a la mayorfa de la humanidad. Las éticas del valor 40 y del discurso suelen olvidar demasiado rápido esta dimensión "protomoral". La consideración de esta dimensión nos obliga a tener en cuenta las dimensiones políticas y económicas del mal, muy poco presentes en las éticas que toman como punto de partida de su reflexión el lenguaje, la conciencia o la razón. Los demás, al intervenir sobre el transcurso de la acción, causan el placer y el dolor, el gusto y el disgusto, la atracción o la aversión, por eso hay un bien y un mal político elemental inextricable en toda acción humana. Ir descubriendo estos males políticos elementales encubiertos por un velo de inocencia es siempre una tarea abierta.

El problema, como ha destacado agudamente Antonio González, consiste en querer elevar el placer, el gusto y el deseo, que son lo primero en el orden moral, al criterio último de decisión moral. Si bien reconocemos en los organismos humanos un umbral de necesidades mínimas, una vez satisfecho este umbral, la capacidad humana para los placeres, los gustos y los deseos se muestra casi infinita, incluyendo la autoflagelación, la tortura, la violación. La solución filosófica del hedonismo

37. La necesidad implica que hay una cosa que la satisface exterior a los mismos actos de placer, gusto o deseo. Es la versión radical de nuestros actos a las cosas y a los otros. Para una revisión de la teoría de las necesidades véase Agnes Heller, Teoría de las necesidades, Barcelona, 1996. En último término, para distinguir entre buenas y malas necesidades, Agnes Heller recurre al criterio de universalidad.

38. X. Xubiri, Sobre el sentimiento y la volición, op. cit., p. 234.

39. I. Ellacuría, "Fundamentación biológica de la ética", ECA, 1979.

40. R. Frondizi, ¿Qué son los valores?, 1972. La crítica de Zubiri a Scheler muestra fehacientemente el ingente platonismo de este tipo de éticas. X. Zubiri, Sobre el hombre, op. cit., p. 204 ss. 
y del utilitarismo ha sido distinguir entre los buenos y los malos placeres, y entre necesidades reales y falsas, dando por supuesto algún tipo de esencia humana, pero esto ya niega el principio de placer mismo. Para persuadir a los individuos de que algunos de sus placeres son falsos, por ejemplo, el placer que experimenta un sádico con el dolor de los otros, necesariamente apelo a algo que va más allá del placer, del gusto y del agrado como criterio último de decisión ética. Mientras distintos teóricos liberales utilitaristas 41 insistirán en que el egoísmo es connatural al ser humano y que el sistema económico actual es el que más se adapta a la naturaleza humana, un autor emotivista como M. Schlick no tendrá reparo en afirmar que para el ser humano lo natural es ser bueno42. En cualquier caso, una ética filosófica rigurosa no tiene por qué dar nada por supuesto y no puede más que ser agnóstica respecto a la verdadera naturaleza o naturaleza última del ser humano.

Además de dar por supuesta una determinada esencia humana, estas corrientes suelen asumir una metafísica individualista, una concepción de los seres humanos como mónadas que se interrelacionan sin apreciar que los demás organizan también nuestros deseos, placeres y gustos. El bienestar para el mayor número es siempre una cuestión de armonización de intereses individuales. Se les hace muy difícil apreciar que el problema de lo bueno, como conjunción de intereses personales y generales, es inseparable del problema de las condiciones sociales y materiales que hacen posible su realización, que el egoísmo, y su contrario el altruismo, tienen prioritariamente que ver con la inserción de los demás y de las cosas en mi acción. Y por otra parte, si bien no puede haber actuaciones ni actividades buenas que no produzcan bienes elementales, tampoco podemos elevar la producción de bienes elementales a criterio último de decisión moral, porque fuera de un umbral de placeres, gustos y deseos, es muy difícil determinar cuáles pueden ser estos bienes elementales. Ni que decir tiene que una sociedad que produjera más bienes elementales que males para todos sería una sociedad altamente moral, pero es justamente este "para todos" que no encontramos en la dimensión protomoral.

\section{Dimensión fáctica de la moral}

Esta dimensión está constituida por la efectiva actuación humana, es decir, por los actos humanos tal como se dan de manera efectiva, independientemente de como estimemos que deberían ser. No olvidemos que la distinción entre acciones y actuaciones es una distinción analítica, de hecho, excepto en algunos casos límites, es casi imposible su separación. Los actos humanos están siempre internamente estructurados. La acción humana adquiere pautas, se modaliza también sin lenguaje y sin conciencia, ya sea mediante adiestramiento o por intervenciones desconocidas de otras acciones humanas. Toda acción tiene que fijarse y orientarse, y es a esta fijación de la acción a la que Antonio González llamará actuación. La mayoría de nuestras acciones son inconscientes, es decir, tienen una orientación, están fijadas, pero ni lo tematizamos ni nos damos cuenta de ello. En estas actuaciones inconscientes caben no sólo los actos que la teoría psicoanalítica considera orientados por el inconsciente, sino todos aquellos actos que realizamos tan cotidiana y rutinariamente que apenas reflexionamos nunca sobre ellos y mucho menos se nos ocurre que puedan ser susceptibles de una valoración moral. La moral se suele circunscribir a la norma, a lo debido, se suele separar del plano fáctico cuando de hecho la norma, la ley moral, los deberes, los tabúes y los valores están siempre encarnados en la actuación, están siempre esculpiéndola. Son esquemas intencionales que modulan la acción misma. Así como no hay un espacio fuera del poder ${ }^{43}$, no hay tampoco una acción fuera de la moral.

Toda actuación sea inconsciente, rutinaria o consciente implica una ensambladura con un esquema intencional, que organiza en forma interna la actuación. Las normas morales, los tabúes, los valores, las reglas y los imperativos, antes que anunciar lo que debe ser, articulan internamente la acción. La internalización de determinados esquemas intencionales es lo más decisivo en el plano fáctico de la moral. El mecanismo por el cual los esquemas intencionales orientan la acción humana es más decisivo que el contenido de un determinado valor o norma. Algunas de estas

41. Hayeck, Sobre la libertad, Costa Rica, 1992. Michael Novak, ¿En verdad liberará?, Costa Rica, 1990.

42. M. Schlick, Problems of Ethics, Nueva York.

43. Judit Ribas, "Apuntes sobre el poder", Voluntad de arraigo, Nicaragua, 1994, p. 234. 
orientaciones de la acción son buenas, por ejemplo, aquella que nos impide matar cuando nos enfadamos con alguien; otras son muy útiles a un determinado grupo social o a un género, por ejemplo, la sujeción de la mujer al varón. Es tal la fuerza y el poder de estos regímenes intencionales, de esta moral física, que muchos de los que se intentan librar de unos esquemas intencionales que los hacen sufrir, se sienten ansiosos, inseguros y culpables, y otros pasan toda una vida sujetos a terapias.

Estos esquemas intencionales establecen en nuestras sensaciones, afectos y voliciones determinadas percepciones, emociones y deseos. Las percepciones, emociones y deseos no son más que sensaciones, afecciones y voliciones orientadas. Las actuaciones se estructuran en posiciones sociales y morales concretas. Las morales concretas son el resultado de múltiples estrategias que poco a poco estructuran las formas de vida de un grupo social. Por ejemplo, la moral fáctica calculadora de la burguesía mercantil permitió un calculo de las pasiones y la introducción de unos esquemas intencionales sexuales que permitían, al mismo tiempo, focalizar la atención ética fuera del mundo laboral. Un número importante de sociólogos se preguntan si el peso dado a las relaciones sexuales en el siglo pasado no servía para proteger las prácticas sociales de la burguesía industrial de la investigación de los moralistas 44. Estos múltiples mecanismos hacen que el resultado producido sea muchas veces independiente del deseo individual. De igual modo, no podemos ver en ellos un plan cínico dirigido. Hay estructuras difusas y mecanismos que producen efectos inesperados.

Los esquemas intencionales de cada grupo social determinan modos múltiples de percibir a los demás, a las cosas y a uno mismo, emociones y deseos diversos. No todos los grupos sociales

han percibido ni perciben del mismo modo al ser humano y a las cosas, ni comparten las mismas emociones ni los mismos deseos. Los grupos sociales se caracterizan precisamente por compartir un mismo régimen 45 de esquemas intencionales, una misma tradición o acervo de recursos simbólicos. Hay tantos grupos sociales como morales concretas y regímenes intencionales. Ahora bien, estas morales concretas, heterogéneas entre sí, están internamente vinculadas, forman sistema. Mientras el límite de un grupo social está definido por la participación en un régimen intencional, en una

44. Gerard Fourez. Liberation Ethics, Philadelphia, 1979, p. 11.

45. Es obvio que los esquemas intencionales forman sistema entre sf. Es lo que Zubiri llama principios tópicos de un grupo social y de una época. Véase X. Zubiri, Sobre el sentimiento y la volición, op. cit., pp. 310, 281. A esta constelación de esquemas la llamamos régimen para enfatizar su carácter de poder. 
moral concreta, el límite de un sistema está definido por el alcance efectivo de las actuaciones sobre los demás y sobre las cosas. De ese modo podemos decir que entre grupos sociales diversos y miembros de culturas muy heterogéneas se establece un mismo sistema moral, aunque no se comparta un mismo régimen intencional. Independientemente del régimen intencional de cada grupo social, sus actuaciones están lastradas, estructuradas por las actuaciones de los demás grupos sociales.

El bien y el mal dependen, en esta dimensión, de los esquemas intencionales de cada grupo social. Estos esquemas intencionales están destinados a elaborar una selección entre los bienes y los males elementales que se han de preferir o sacrificar. Ahora bien, aquí sólo podemos juzgar sobre el carácter bueno o malo de nuestra actuación, a partir de la moral concreta de cada grupo social. En estos regímenes intencionales, a veces, hay muchas coincidencias, pero también muchas diferencias y hasta conflictos entre ellos. Por otro lado, son a veces insuficientes para enfrentar nuevos problemas, piénsese, por ejemplo, en la ingeniería genética, los problemas entorno al inicio y el fin de la vida o los límites ecológicos del planeta. Además, para enjuiciar moralmente una actuación no basta con recurrir a los esquemas intencionales de un determinado grupo social, si tenemos en cuenta que esta actuación se integra en un sistema moral mundial. La selección entre bienes y males que brinda el régimen intencional de cada grupo social no suele contemplar los efectos y las consecuencias de la acción sobre otros grupos sociales dispares. Del mismo modo como el psicoanálisis muestra las cárceles terribles que pueden constituir la impronta inconsciente de las percepciones, emociones y deseos de los demás sobre nuestra propia actuación, los grupos sociales no son a menudo conscientes de cómo sus actuaciones lastran las actuaciones de otros grupos sociales. La estrategia común de algunos grupos sociales en sus respectivos regímenes morales suele ser el desplazar el centro de gravedad del acto moral a la intención con que se realiza, con independencia de los resultados obtenidos y de las consecuencias que nuestro acto tenga sobre los demás.

De hecho, podemos juzgar con mucha más propiedad las actuaciones que los individuos, pues las actuaciones son mucho más evidentes que cualquier buena intención o ámbito oscuro que permaneciera detrás. Podemos juzgar una actuación aunque no hubiera siquiera una responsabilidad social en ella, ni una conciencia de sus actores. Es decir, cuando ni tan solo es esperable que un grupo social sea consciente de ello. Con todo, no se trata de moralizarlo exhaustivamente en su totalidad. Foucault nos hace ver muy bien como lo que se presenta como proyecto liberador constituye muchas veces una nueva e inusitada cárcel. Más bien de lo que se trata es de moralizar las acciones relevantes y de desmoralizar las irrelevantes. Así, es frecuente que actuaciones de los seres humanos perfectamente inocuas, irrelevantes e inocentes estén cargadas de ingentes códigos morales y sometidas a toda suerte de escrúpulos éticos, mientras que las acciones más decisivas, las que deberían someterse al mayor de los rigores morales, apenas sean objeto de consideración moral46. Es la permanente estrategia del poder, se culpabilizan actos triviales y se trivializan los actos más decisivos. En la medida en que me distancio de mis actuaciones y las actuaciones de mi grupo social, en la medida en que problematizo mis códigos morales, mis actos no son ya meras actuaciones, sino actos racionales. Podemos llamarlo quizás con otro nombre, pero lo que queremos describir aquí son aquellos actos de los seres humanos que, en toda época y lugar, suelen rebasar las actuaciones concretas, que suelen tender a cambiar los regímenes intencionales, los códigos morales y las actuaciones mismas.

\section{Dimensión racional de la moral}

Si la estructura de la acción humana misma, la dimensión protomoral, nos impone el tener que adoptar una determinada actuación, las actuaciones a su vez están permanentemente abiertas a una dimensión racional. En los actos racionales nos preguntamos cuál de los esquemas intencionales es más interesante, creamos nuevos esquemas intencionales, modificamos las actuaciones o creamos nuevas actuaciones. Es lo que Antonio González llama actividad, apropiación de una determinada posibilidad de actuación. Mientras la actuación está lastrada por el pasado, la actividad está abierta hacia el futuro. Es el momento optativo

46. A. González, “Orden mundial y liberación”, Diakonía 74 (1994). 
de la acción, de apropiación de una determinada posibilidad para actuar. Los actos racionales consisten en intelección y probatura de distintas posibilidades. La acción y la actuación nos lanzan a tener que elegir entre distintas posibilidades de actuación o a crear nuevas actuaciones. No elegir, no optar, mantener una misma actuación es también elegir. El acto irracional es propiamente también un acto racional. Es aquel acto por el cual nos forzamos a no salir del ámbito de nuestras actuaciones. A resistir la tendencia hacia la apertura de nuestra acción. Toda actuación es moral y toda actividad es igualmente racional, pero del mismo modo que a la actuación que no es acorde con el régimen intencional de un determinado grupo social la llamamos, en el lenguaje común, acto inmoral, no toda actividad racional se realiza acorde con las tendencias de la razón y esto es justamente lo que podemos llamar actos irracionales 47 . Las sensaciones, las emociones y los deseos no son el ámbito de lo irracional. Precisamente, el ser humano realiza actos racionales por su peculiar manera de gozar, disfrutar y desear. La racionalidad no está por encima de la sensibilidad, sino que se inscribe en la estructura del sentir humano. Hay deseos, placeres y emociones que son profundamente racionales. La actuación racional, aunque no siempre se identifica con lo que apetece, gusta, hace feliz o emociona, no se opone intrínsecamente a ello.

Entre los actos racionales dirigidos a apropiarse de una posibilidad de actuación podemos distinguir los actos de justificación moral y los actos de creación moral. Por los primeros se marcha más allá de la tradición y de la costumbre, del "así es", "así se ha hecho siempre", o "así lo hacen los demás" y se escoge entre distintas posibilidades de actuación, apelando a los criterios mismos que nos ofrece el régimen moral vigente. Por los segundos se pone en tela de juicio todo un régimen intencional, ya no se trata de justificar determinadas actuaciones, sino la moral concreta en su conjunto. Se introducen esquemas intencionales radicalmente nuevos, distintos a los que caracterizaban a cierta moral concreta.

Algunas de estas posibilidades apropiadas pueden volver "natural" lo que hasta hace poco era considerado inmoral, y a la inversa. Piénsese tan solo en las prácticas sexuales homosexuales, que eran un tema tabú hasta hace bien poco y que hoy son una práctica cada vez más aceptada, o en la usura, que para Aristóteles y santo Tomás constituía una perversión y que, sin embargo, hoy no hay nada más común, para importantes sectores de la sociedad, que la obtención de intereses por el dinero. Por la propia naturaleza de la actividad, la apropiación de posibilidades, nunca nos queda absolutamente impuesta una u otra actuación moral. Es más, si la hubiera, sería la negación del ámbito moral humano, que es constitutiva apertura de la acción. Mientras la actuación tiende a clausurar este carácter de apertura radical de la acción humana, la actividad racional tiende a abrirla en forma permanente.

Los actos humanos, a los que llamamos racionales, por tener la característica de buscar lo que las cosas podrían ser con independencia de nuestros actos, tienen una gran importancia para orientar nuestras acciones. Piénsese en un asunto tan intrascendente como comprar juguetes bélicos a los niños. Si la investigación psicológica nos muestra convincentemente que jugar con juguetes bélicos en la infancia potencia la destructividad de los futuros adultos o que, por el contrario, tiene efectos meramente catárticos, habría que tomar en consideración estos nuevos conocimientos para orientar la acción. Los actos racionales no buscan actuar con absoluto conocimiento de causa, ni llegar a tener la razón, sino que propician un disenso permanente $y$, en consecuencia, un diálogo inacabable. Tampoco son actos que pretendan juzgar y valorar desde un punto de vista superior, imparcial o desinteresado. Los actos racionales parten siempre de determinadas actuaciones y consisten en la critica de la actuación, en su refutación, corrección o creación de nuevas actuaciones. Aquí no encontramos normas el ámbito de la norma es el de la actuación. La actividad racional tampoco se opone a la imaginación, al contrario, los actos racionales son imaginativos y el bien racional es aquel que, en buena parte, seamos capaces de crear.

De hecho, ningún acto racional humano es igual, lo cual nos aleja de ciertas concepciones esencialistas y ahistóricas, sostenidas por algunas corrientes

47. Para Zubiri, a diferencia de Hegel, lo irracional es racional, es un modo de actualidad de lo real opaco. Lo irracional es un tipo, entre otros, de dar razón de las cosas o de mí mismo. Véase X. Zubiri, Inteligencia y razón. Madrid, 1983, p. 79. 
neoilustradas. La intelección racional procede siempre a partir de lo inteligido previamente y está fijado por un logos o tradición cultural. No hay propiamente razón autónoma, sino que siempre está lastrada por los modos de pensar y las estructuras lingüísticas de la tradición de la que parte. La provisionalidad, la historicidad y la contextualidad de la razón no sólo proceden de su punto de partida, sino de la apertura misma de la razón que, por su constitutiva alteridad, hace que siempre su contenido fundamental se actualice problemáticamente. Siempre es una razón en búsqueda de la "hondura insondable" de la realidad48. Pero, el descubrimiento de una tipificidad en el análisis de estos actos racionales nos aleja también de aquellas metafísicas postmodernas que rechazan todo carácter universal de la razón y postulan múltiples racionalidades inconmensurables. Lo que nos muestra el análisis es que a pesar de las grandes disparidades que puede haber entre actos racionales ejecutados en una u otra cultura y entre diferentes tipos de los mismos (poético, científico, etc.), hay elementos coincidentes entre ellos.

Los actos racionales están, por su misma estructura, impelidos a trascender tanto mis bienes elementales como todos mis esquemas intencionales de índole moral. Se trata del dinamismo mismo de la razón, no de un deber imperativo. Nuestra razón es constitutivamente crítica. La posibilidad misma de renunciar a este dinamismo, de encerrarse en la propia cultura, tradiciones y consensos, de no salir nunca del ámbito de la actuación, de actuar irracionalmente, es una posibilidad otorgada por este dinamismo. Este dinamismo universal de la razón no depende de la historia o de la naturaleza, sino del momento de alteridad, inscrito en todos nuestros actos, que nos invita siempre y en forma permanente a trascender nuestras actuaciones. El contenido de las actividades es muy abierto; sin embargo, este dinamismo de la razón es universal. La fuerza de la alteridad que nos arrastra e impele no es una pura opción. Claro está, puedo eludir actuar racionalmente, pero esta posibilidad misma de esquivar la fuerza de la alteridad nos muestra, en el límite, cómo las actuaciones son trascendidas y cómo no puedo soslayar nunca, en definitiva, el problema de la actuación, el problema moral mismo. En el análisis de los actos racionales podemos distinguir cuatro tendencias de los actos racionales, susceptibles de constituir a su vez criterios u orientaciones racionales de actuación: una tendencia liberadora, otra dialógica, otra igualitaria y otra universalizadora.

Por la tendencia liberadora, los actos racionales nos distancian de las actuaciones. Al sumergirnos en la alteridad de nuestros actos adquirimos una cierta independencia o distancia de las cosas, de los demás y de nosotros mismos. Frente a la obligación y el mandato de la actuación y de sus mecanismos, a menudo mecánicos y repetitivos, los actos racionales cuestionan, critican, crean e inventan. Los actos racionales de toda índole (científicos, poéticos, etc.), a menudo enfrentan a los individuos con las categorías vigentes. Mientras el entendimiento es el ámbito del consenso, la razón constituye el ámbito del disenso. La razón es constitutivamente libre 49 . Por este criterio de libertad podemos decir que cuando menos fruto sea de la coacción una determinada actuación, es moralmente más racional.

Por la tendencia dialógica, los actos racionales me invitan a verme desde fuera, a verme desde la perspectiva de la otra, del otro, y de los códigos morales de otros grupos sociales. Hay, irremisiblemente, en la propia estructura de los actos

48. "La profundidad tiene hondura insondable. La intelección en profundidad es un hecho; pero el acceso a la ultimidad es constitutivamente un problema siempre abierto hasta el infinito". X, Zubiri, Inteligencia y razón, op. cit., p. 168.

49. X. Zubiri, Inteligencia y razón, op. cit. 
racionales una tendencia a trascender los propios criterios, a ver mi realidad junto a otras. Se trata de un dinamismo de relativización de mi punto de vista, de mis intereses entre otros intereses, de mi cultura que aparece entre otras culturas. Por su propio dinamismo, la razón es razón del otro. Por esta tendencia podemos decir, con Levinás y Dussel, que estamos en deuda con la otra y el otro, aun cuando no le hubiéramos afectado nunca. Desde este criterio de responsabilidad se puede afirmar que cuanto más relativice mis propias actuaciones y las de mi grupo social, cuanto más me compenetre y preocupe por los otros extraños a mi cultura y a mis valores, más racional es mi actuación. A partir de este criterio no sólo se puede cuestionar que haya unas formas morales universales alcanzables sólo en un proceso evolutivo de desarrollo y que las sociedades "desarrolladas" posean el estadio moral superior (el estadio postconvencional) como quiere Kolberg50, sino que se podría sospechar incluso de su racionalidad, si se muestran en el plano fáctico los efectos reales de las actuaciones de estos grupos sociales sobre los demás grupos sociales del planeta.

Por la tendencia igualitaria de mis actos racionales mi realidad es vista como una realidad más entre la de los demás. Desde la razón no hay privilegios de unos sobre otros. Aplicando este criterio de justicia resultarán moralmente aceptables aquellas actuaciones que no tiendan a preferir mis bienes y virtudes a los bienes y virtudes de los demás.

Por la tendencia universal, todos los contenidos de mis acciones y mis actuaciones morales tienden a ponerse en el mismo plano que los contenidos morales de las actuaciones y las acciones de los demás. Ello me obliga a plantearme en forma crítica si mis bienes y virtudes no atentan contra los de los demás. Desde este criterio de universabilidad resultarán moralmente aceptables aquellos bienes y virtudes que pueden ser aceptados por cualquiera, sin dañar los bienes y virtudes de los demás. El último criterio es el más relevante para orientar nuestras actuaciones en un sistema moral mundial, pues aun satisfaciendo los otros criterios, los criterios de libertad, responsabilidad y justicia, mi actuación puede continuar siendo inmoral, si dafía e impide los bienes de los demás, mientras que no sucede exactamente a la inversa. Aunque mis actos estén regidos por el egoísmo y la búsqueda del interés personal, aunque no me responsabilice del otro, y aunque actúe coaccionadamente, si de hecho no daño los bienes y virtudes de los demás, mi actuación es aceptable. $Y$ es que muchas actuaciones consideradas inmorales constituyen, en realidad, actuaciones racionales y a la inversa, muchas actuaciones consideradas morales son bastante irracionales. El criterio de universalidad posibilita un amplio margen de tolerancia y pluralismo entre los diferentes actores y grupos sociales. Posibilita una tolerancia y un pluralismo que no esconden las relaciones de poder, las relaciones políticas de unos sobre otros.

\section{La fundamentación ética}

Para evitar imprecisiones en el uso del término fundamento, es útil una distinción de raigambre zubiriana. Una cosa es la fundamentación como creación de la razón, creación de lo que pueden ser los contenidos de la realidad en profundidad, allende la aprehensión, por ejemplo, el sol ahora me acaricia la piel y en mi cultura el fundamento de ello es una teoría astronómica siempre provisional que me explica este hecho, y otra cosa es la fundamentación como intento de descripción de los hechos inmediatamente dados, el análisis de estas impresiones inmediatas que me están produciendo una sensación agradable. En el primer sentido, la cuestión del fundamento es algo siempre abierto. Es lo que hemos llamado actos de creación moral. En el segundo sentido de fundamentación, no se pretende ningún género de explicación teórica, sino una descripción asequible para cualquiera, independiente de la cultura, las teorías científicas y la tradición de cada cual, una descripción de la situación primigenia e inmediata en la que estamos. Se trata de avanzar hasta donde nos sea posible en la clarificación de esta situación "originaria". Y esto tiene cuanto menos una preciosa ventaja: aunque la descripción sea mejorable, aquí no está dicho que no podamos llegar a algo que sea confín, al menos es obvio que el análisis de hechos positivos 51 es mucho más cerrado que la creación teórica. Por

50. Martín Baró, Acción e ideología, op. cit., p. 155.

51. Los hechos positivos, a diferencia de aquello positivamente actualizado en la aprehensión (positum) y de los hechos cientificos, son precisamente datos que por su propia índole son aprehendibles por cualquiera. 
cuanto esta constatación es primera y radical, es tarea anterior a toda construcción - teoría del conocimiento, psicología, ciencia en general, metafísica- y traza el marco en el cual toda labor teórica encuentra su fundamento y su valor. El término "fundamento" no es impropio, porque aquí el fundamento apela a una instancia inmediata aprehendible para cualquiera que sostiene las teorías científicas y metafísicas indicándonos sus orígenes, su sentido y sus límites, pero no debe confundirse con la fundamentación racional, pues casi se trata de un movimiento inverso.

En este esfuerzo descriptivo reside, pues, la tarea del análisis ético. Cuanto más riguroso sea el análisis, mayor fuerza tendrá la fundamentación. Ahora bien, se podría acusar a esta descripción de caer en la falacia naturalista que, dicho sea de paso, se ha convertido en una especie de arma arrojadiza entre diferentes análisis e intentos de fundamentación ética. Aseguraba al principio que la apelación a las diversas ciencias suele incurrir en la falacia naturalista y ahora parece que haga prácticamente lo mismo, al derivar de unas tendencias de los actos racionales criterios de actuación. Ciertamente, no vamos, como el naturalismo ético, a la realidad para encontrar criterios morales de actuación, pero se nos podría argüir que estamos pretendiendo derivar de juicios descriptivos, de la descripción de la acción humana, juicios valorativos. Pero, ¿constituye esto, en el caso concreto de la acción humana, una falacia?

Desde la perspectiva lógica es imposible obtener conclusiones con un "debe", a partir de premisas en las que sólo aparece un "es". Pero el problema lógico se soluciona introduciendo un debe en la premisa, diciendo que la naturaleza humana tiene un carácter debitorio. La falacia naturalista consiste en identificar el bien con alguna propiedad natural, por ejemplo, cuando identifica lo bueno con lo placentero. Moore52 argumenta que, de hecho, ninguna descripción de una propiedad natural puede clausurar la pregunta moral. La cuestión moral es intrínsecamente una cuestión abierta, permanece siempre como una open question. Hay moral porque hay apertura y de aquí la insatisfacción de todas las fundamentaciones morales que pretendan identificar el bien con algo. Lo que Moore denuncia no es la falacia de derivar juicios éticos de juicios naturales sino, al contrario, la falacia de reducir juicios éticos a juicios sobre eventos naturales. Dicho de otro modo, no es siempre falaz derivar orientaciones éticas de un conocimiento descriptivo de algo que es intrínsecamente moral, que tiene que apropiarse de posibilidades, pero sí es falaz reducir todo juicio ético a juicio descriptivo, naturalista o factual. Constituye un vano intento para ignorar la constitutiva apertura de la acción humana, su estructura debitoria53. Lo que encontramos legítimamente en nuestro análisis son orientaciones y aunque ninguna de ellas basta para despejar en su totalidad la incertidumbre, constituyen, en su conjunto, indicaciones importantes para orientar la acción.

Kant evita la falacia naturalista afirmando que hay un factum moral, un hecho de razón, un imperativo categórico o especie de juicio sintético a priori de tipo moral anterior y por encima de cualquier acción humana, cuya forma no es otra que la universalidad. Nos asegura que el elemento moral de una acción humana es una especie de necesidad, que no se da en la naturaleza y que consiste en una obligación incondicional de la razón, por la cual una acción humana es buena en sí misma con independencia de fines y normas. Es la razón pura la que prescribe la ley moral. Kant piensa que todas las éticas existentes hasta él no eran propiamente éticas, que habían resbalado sobre la esencia de la moralidad. La moralidad consiste en este hecho de razón, es inmoral el que no actúa conforme a él. Kant no se hace ilusión alguna sobre los móviles reales de nuestra conducta y sobre nuestra capacidad de racionalización. Aun si en el examen más sutil no encontramos nada fuera del principio moral del deber, que nos pueda haber movido a hacer tal o cual acción, de aquí no se puede concluir que la auténtica causa "determinante de la voluntad no haya sido un impulso secreto de amor propio"54. También nos advierte que, a medida que uno envejece, duda cada vez más de que se encuentre en el mundo alguna virtud auténti-

Para una distinción crucial entre positividad, hecho positivo y hecho cientifico véase X. Zubiri, Inteligencia y razón, op. cit., p. 181 y ss.

52. G. F. Moore, Principia Ethica, 1903.

53. X. Zubiri, Sobre el hombre, op. cit.

54. I. Kant, Fonamentación de la metafisica dels costums, Barcelona, 1984, p. 88. 
ca e incluso de que hayan existido alguna vez acciones conforme al deber. Pero aunque no encontremos en la experiencia nada que obedezca al imperativo categórico, éste se encuentra irremisiblemente en la razón.

Ahora bien, ¿es que consiste propiamente este "factum de razón"? ¿Se da una especie de relación extrínseca y de oposición entre la moral y el sentir humano? Nuestro análisis integra de algún modo la intuición kantiana, desde el momento en que apreciamos como algo dado una tendencia universal en todo acto racional, sin tener que presuponer ninguna metafísica ni antropología para fundamentar la ética. En la fundamentación ética de Apel también rezuma una cierta metafísica racionalista: los elementos de la finitud, la facticidad, la constitución de sentido son pensados finalmente como límites, como obstáculos, cuya eliminación paulatina es imprescindible para una implantación progresiva de la racionalidad argumentativa. El diálogo parece apuntar hacia su autodestrucción, la comunidad racional lograda acabaría con la comunicación misma, el diálogo ya no sería necesario55. En nuestro caso, tropezamos con una tensión u oposición insoluble entre razón y logos, entre actuaciones y actividad, no regida por el principio de superación y no clausurable. La racionalidad a la que accedemos no consiste en hacer que impere la razón (normalmente, la razón de unos pocos), sino en argumentar sin fin.

\section{Conclusiones}

La fundamentación moral es fruto de un análisis del hecho moral, tarea que hemos empezado adscribiendo a la ética filosófica. Este análisis no nos brinda un criterio absoluto, pero nos da un conjunto no despreciable de orientaciones. Cada una de las dimensiones analizadas reivindica sus fueros. La dimensión protomoral nos muestra cómo hay unos bienes y males elementales, ligados al ámbito sensomotor de las acciones. Su exacerbación nos puede llevar al biologicismo ético. La dimensión fáctica de la moral nos muestra cómo toda actuación se rige por un régimen intencional, que pretende hacer una selección adecuada entre bienes y males elementales. Su exacerbación nos puede llevar a múltiples actuaciones irracionales. La dimensión racional de la moral nos lleva a interrogarnos sobre las actuaciones posibles e incluso a crear nuevas actuaciones, pero la exacerbación de esta dimensión puede llevarnos también a la parálisis y a un universo patológico e invivible. El equilibrio entre estas dimensiones es justamente el arte moral para el cual no hay recetas.

La pregunta por la universalidad ética que nos hacíamos al principio, no halla su respuesta en una fe moral, sino en la pulcritud del desarrollo de una ética filosófica, entendida como filosofía primera. Podemos distinguir tres niveles en la universalidad a que accedemos mediante la ética filosófica. El primer nivel, y el más decisivo, es la propia universalidad del análisis, con pretensión de ser válido, independientemente de cualquier cultura y accesible para cualquiera, en la medida en que no obliga a presuponer ninguna teoría antropológica o metafísica para el mismo. En este plano llegamos a detectar unas estructuras universales en la dimensión protomoral, en la dimensión fáctica y en la dimensión racional de la moral. El segundo nivel se circunscribe al momento o tendencia universal hallada en los actos racionales humanos, y el tercer nivel se refiere a la universalidad fáctica, a la existencia, por primera vez en la historia, de un sistema moral universal o de una comunidad real de comunicación mundial. Si bien este tercer nivel no se deriva inmediatamente del análisis, pues para establecerlo se necesita del concurso de las ciencias, en cierto modo nos aboca a él $y$, en todo caso, a diferencia de otros planteamientos, no se cierra a la percepción de esta universalidad fáctica.

A partir de este análisis, palabras como diversidad, multiculturalidad, derecho a la diferencia, fragmentación y sus contrarios, unidad, uniformidad, derecho a la igualdad y universalidad, mezcladas y utilizadas muy profusamente en todo tipo de discursos, y utilizadas como argumentos ideológicos, tanto por la derecha como por la izquierda56, encuentran precisión y claridad teórica. La apelación al pluralismo, a la diferencia y la multiculturalidad sólo es legítima esforzándonos por ver lo que tiene de no universalizable y excluyente, y de dañino para las posibilidades de los demás, para cada una de las formas de vida en el planeta. La referencia a la universalidad sólo es plausible

55. Victoria Camps, La imaginación ética, Barcelona, 1992.

56. F. Fernández Buey, "El racismo diferencialista", La barbarie, 1995; Todorov, Nosotros y los otros, 1992. 
reconociendo el margen amplísimo para la diferencia y el pluralismo en las prácticas de todo tipo (económicas, políticas, culturales, sexuales, etc.). En el límite no sólo no hay ninguna forma de vida igual a otra forma de vida, sino que no hay ningún acto igual en ninguna forma de vida. El desarrollo riguroso de una ética primera puede responder a los anhelos expresados por la reflexión ética mesoamericana de una verdadera universalidad y a la insatisfacción que producen muchos de los planteamientos vigentes. 